\title{
TREATMENT AND DIAGNOSTIC TACTICS IN CHILDREN WITH FOREIGN BODIES IN GASTROINTESTINAL TRACTS
}

\author{
Barskaya M.A. ${ }^{1}$, Zavyalkin V.A., ${ }^{1}$ Varlamov A.V. ${ }^{2}$, Kuzmin A.I. ${ }^{1}$, Rodionov V.G. ${ }^{2}$, \\ Timashev I.V. ${ }^{2}$, Busov N.A. ${ }^{2}$, Terechina M.I. ${ }^{1}$ \\ ${ }^{1}$ Samara State Medical University, Samara, Russiae-mail: zavv@ rambler.ru; \\ ${ }^{2}$ Samara Regional Clinical Hospital named after V.D.Seredavin, Samara
}

Aims.

Study aim: Development of a treatment and diagnostic algorithm for children with foreign bodies of the gastrointestinal tract

Materials and Methods

This study is based on the analysis of the treatment results of 467 children (from infants to 15 years of age) with foreign bodies that entered gastrointestinal tract either when swallowed by accident or on purpose.

Results.

In $409(87.5 \%)$ of 467 patients, foreign bodies exited naturally 3-5 days after being swallowed. In 41 (8.7\%) of cases, foreign bodies were removed from the stomach via fibrogastroduodenoscopy. Surgical interventions were performed on 17 children due to complications caused by the foreign bodies. In 15 patients, peritonitis was diagnosed prior to the surgery, in two - intestinal obstruction. Chemically and physically active foreign bodies frequently caused complications The examples of the diagnosis and treatment of children with such complications are described.

Conclusions.

Based on the obtained information, treatment and diagnostic tactics of treatment of children with foreign bodies of the gastroduodenal tract have been developed.

Key words: foreign bodies of the gastrointestinal tract, diagnostics, treatment, children

\section{INTRODUCTION.}

Foreign bodies found in the digestive-intestinal tract include objects that entered the digestive tract from outside or those that developed inside the organism and cannot be utilized as food [1]. In children, foreign bodies primarily penetrate via the alimentary tract by accidental or intentional swallowing of non-edible objects. Usually, such cases are observed in children younger than 5 years old [2]. Children do not always inform their parents about such accidents. Thus, parents ask for medical help only when the child starts complaining or their behavior changes. In this situation, it is quite difficult to provide early diagnostics [3].

Most commonly, children ingest such objects as beads, buttons, coins, toy parts, pits, etc. Usually, these objects pass spontaneously and uneventfully through the gastrointestinal tract [1].

Foreign bodies in the gastrointestinal tract are divided into inert (coins, beads, etc.), chemically (batteries), physically (magnets) and mechanically active (needles, pins, etc.) [4].

Special attention should be paid to chemically active (batteries) and physically active (magnets) foreign bodies that damage the gastric and intestinal walls and lead to severe complications, like peritonitis or intestinal obstruction $[1 ; 3 ; 5 ; 6]$, that require multiple surgical interventions.

The study was aimed to develop a diagnostic and treatment algorithm for children with foreign bodies in the gastrointestinal tract. 
From 2011 to 2016, 467 children (from infants to 15 years of age) with foreign bodies in the gastrointestinal tract were treated in the surgical department of the Samara Regional Clinical Hospital named after V.D. Seredavin (Table 1). The study included 290 male (62.1\%) and 177 female $(37.9 \%)$ patients.

The study protocol followed guidelines for experimental investigation with human subjects in accordance with the Declaration of Helsinki and was approved by the ethics committee. Written informed consent was obtained from each patient (or official representative) before the study.

Table 1. Distribution of the observed patients by sex and age

\begin{tabular}{|c|c|c|c|c|c|c|}
\hline \multirow[b]{2}{*}{ Sex } & \multicolumn{5}{|c|}{ Age } & \multirow[b]{2}{*}{$\begin{array}{c}\text { Total, abs., } \\
\%\end{array}$} \\
\hline & $\begin{array}{l}\text { Up to } 1 \\
\text { year }\end{array}$ & $\begin{array}{c}1-3 \text { years } \\
\text { old }\end{array}$ & $\begin{array}{c}\text { 4-7 years } \\
\text { old }\end{array}$ & $\begin{array}{c}8-12 \text { years } \\
\text { old }\end{array}$ & $\begin{array}{c}13-15 \\
\text { years old }\end{array}$ & \\
\hline Male & 2 & 110 & 152 & 20 & 6 & $290,62.1 \%$ \\
\hline Female & 1 & 64 & 73 & 29 & 10 & $177,37.9 \%$ \\
\hline Total, abs., \% & $3,0.6 \%$ & $174,37.3 \%$ & $225,48.2 \%$ & $49,10.5 \%$ & $16,3.4 \%$ & $467,100 \%$ \\
\hline
\end{tabular}

The absolute majority of children were of toddler and pre-school age -402 children $(86.1 \%)$.

The types of foreign bodies found in 467 children included:

- magnets - $17(3.6 \%)$;

- batteries - $49(10.5 \%)$;

- coins - $117(25 \%)$;

- screw nuts - $5(1.1 \%)$;

- baptismal crosses - $6(1.3 \%)$;

- pins, needles, clips - 9 (1.9\%);

- toys $-8(1.7 \%)$;

- glass - $10(2.1 \%)$;

- decorative stones - $6(1.3 \%)$;

- decorations - $11(2.4 \%)$;

- plastic toy and constructor parts - $18(3.9 \%)$;

- other - $211(45.2 \%)$.

In general, $376(79 \%)$ inert, $19(4.1 \%)$ mechanically active, 17 (3.6\%) physically active, and $49(10.5 \%)$ chemically active foreign bodies were detected.

\section{RESULTS.}

The absolute majority of patients that applied to the pediatric department of the Samara Regional Clinical Hospital with foreign bodies in the gastrointestinal tract reported the ingestion of some objects (459).

In 8 cases, during medical history taking, no information was provided on the possible 
ingestion of foreign bodies. These patients applied to the Hospital complaining about abdominal pains with suspected acute abdominal surgical pathology. Two patients were directed to the Hospital with intestinal obstruction, six patients - with peritonitis. In two children, who were directed to the Hospital with intestinal obstruction, foreign bodies in the abdominal cavity were revealed in a plain abdominal radiographic image. In six patients, who were operated for peritonitis, foreign bodies were revealed during surgery.

All the children underwent a thorough clinical examination, laboratory studies (CBC and UA, other methods of laboratory diagnostics were carried out when indicated), plain abdominal radiography and ultrasonography.

If a foreign body was revealed in the stomach by the X-ray study (radiopaque object), fibrogastroduodenoscopy (FGDS) and removal of the foreign body were performed. FGDS was also indicated to patients who had ingestions of non-radiopaque objects in the anamnesis for their removal from the stomach.

When a foreign radiopaque body was revealed in a small or large intestine by plain abdominal radiography, an observational tactic with an obligatory plain abdominal radiographic control of the passage through the gastrointestinal tract was chosen.

If it was impossible to remove a foreign body during FGDS and complications developed (like in cases with physically and chemically active foreign bodies), surgical treatment was performed.

In $409(87.5 \%)$ out of 467 patients, foreign bodies passed through naturally in 3-5 days after the ingestion. In $41(8.7 \%)$ cases, foreign bodies were removed from the stomach during FGDS. Surgery for complications caused by foreign bodies was performed in 17 children.

In 15 patients before the surgery, peritonitis was diagnosed, in 2 patients - intestinal obstruction.

The fact of foreign body ingestion was established in 9 out of 15 patients operated for peritonitis. In 6 cases, foreign bodies in the gastrointestinal tract were revealed during the surgery.

\section{Clinical case.}

An 11-year old girl was admitted to the surgical department with complaints about abdominal pain, nausea, one time vomit, an increase in the temperature to $37.7^{\circ} \mathrm{C}$. The symptoms started 3 days before. There was no information on the ingestion of foreign bodies. The patient's condition at the admission was moderately severe. By the results of clinical, laboratory, and X-ray studies (Figure 1), the patient was diagnosed with "Foreign body in the intestine, peritonitis". 


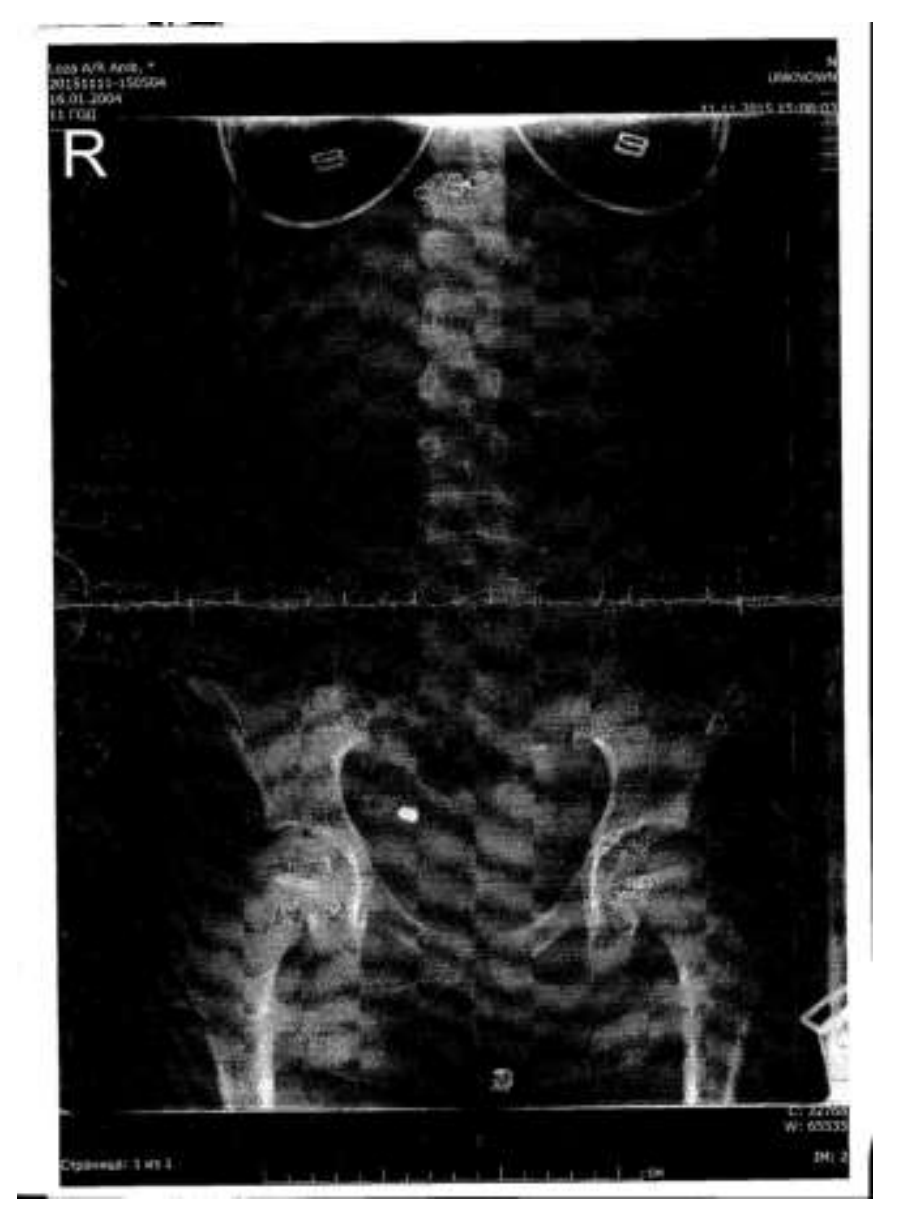

Figure 1. X-ray image of patient K. Steel foreign matter in the ileocecal area.

After the pre-surgical preparation, the surgeons performed laparoscopy, revision of abdominal organs, liquidation of the ileocecal fistula that developed on two magnet foreign bodies (beads, $7 \mathrm{~mm}$ in diameter), removal of foreign bodies from the intestine, and omentum resection.

After the surgery, the patient was diagnosed with magnet foreign bodies in the intestine, ileocecal fistula, omentitis.

The postoperative period was without complications. The patient was discharged in a satisfactory condition on the $9^{\text {th }}$ day.

Two children with foreign bodies in the gastrointestinal tract were operated for intestinal obstruction.

One of them had multiple foreign bodies and intestinal obstruction.

Clinical case.

Patient B. (6 years old) was admitted to the pediatric surgical department with complaints about abdominal colicky pain and multiple vomits.

Plain abdominal radiography was performed. Multiple foreign bodies were revealed (Figure 2). 


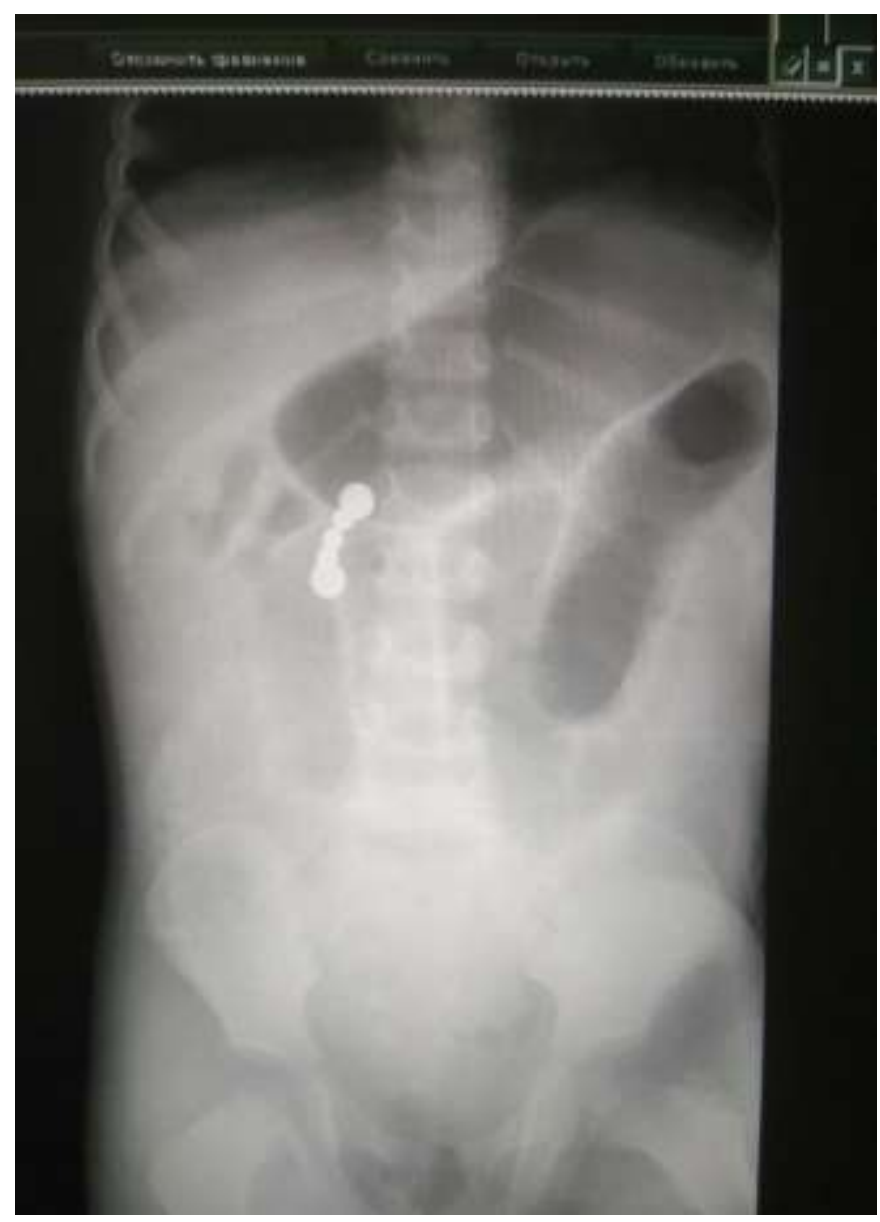

Figure 2. Plain abdominal radiography. Patient $B$.

The pre-operation diagnosis was multiple foreign bodies in the intestine, intestinal obstruction. After the pre-surgical preparation, the surgeons performed the median midline laparotomy. Swollen and cyanotic loops of the small intestine were revealed. The intestinal revision showed foreign bodies in the jejunum $50 \mathrm{~cm}$ from the ligament of Treitz. The foreign bodies adhered to an ileum loop with other foreign bodies. Adhesion of the inflamed part of the greater omentum was observed. After the separation of the loops of the small intestine and the resection of the altered part of the greater omentum, 2 perforations $(1.5 \times 1.0 \mathrm{~cm}$ and $1.0 \times 0.8 \mathrm{~cm})$ with necrotized edges and prolapsing foreign bodies ( 2 magnet beads and two 10 kopek coins) attached magnetically to each other. Foreign bodies were removed. Dissection of wound edges and suturing of intestinal defects were performed. Intestinal loops turned pink, mesostenium vessels started to pulsate. The lavage of the abdominal cavity was performed and the operative wound was sutured.

There were no complications observed in the postoperative period. The patient was discharged in a satisfactory condition on the $11^{\text {th }}$ day.

There were no lethal outcomes registered during the study.

The analysis of the results of the treatment of children with foreign bodies in the gastrointestinal tract showed that it was feasible to follow the proposed diagnostic and treatment algorithm: 
- Thorough taking of the anamnesis for the identification of possible ingestion of some objects by the child.

- $\quad$ Clinical tests.

- $\quad$ Plain abdominal radiography.

- $\quad$ Abdominal ultrasonography.

- $\quad$ FGDS for patients with radiopaque foreign bodies localized in the stomach.

- $\quad$ FGDS for patients with the fact of ingestion of non-radiopaque objects in the anamnesis if they are located in the stomach.

- Observational tactics with obligatory X-ray control of the radiopaque foreign body in the small or large colon.

- Surgical intervention in the case of development of complications (peritonitis, intestinal obstruction).

\title{
CONCLUSIONS
}

1. Foreign bodies in the gastrointestinal tract are often observed in children, especially in toddler and pre-school age.

2. The diagnostic and treatment procedures for children with foreign bodies in the gastrointestinal tract should be performed according to the described algorithm.

\author{
FINANCIAL SUPPORT AND SPONSORSHIP \\ Nil.
}

\section{CONFLICTS OF INTEREST}

The authors declare no conflict of interest

\section{SUPPLEMENTARY DATA (DOI)}

\section{REFERENCES}

1. Isakov Iu.F., Razumovskii A.Iu. Children's surgery: textbook [Detskaia khirurgiia: uchebnik], Moscow, GEOTAR-MEDIA, 2014, 1036 p.

2. Beburishvili A.G., Mandrikov V.V., Akinchits A.N. Foreign bodies of the ventricular tract: tutorial [Inorodnye tela zheludochno- kishechnogo trakta: uchebnoe posobie]. Volgograd, Izd-vo VolGMU, 2007, 32 p.

Khalafov R.V. Foreign magnetic bodies of the gastrointestinal tract in children (clinic, diagnostics and treatment options): autoreferat thesis of the Candidate of Medical sciences [Inorodnye magnitnye tela zheludochno-kishechnogo trakta u detei (klinika, diagnostika i varianty lecheniia): avtoreferat dissertatsii kandidata meditsinskikh nauk], Moscow, 2015, 20 p.

3. Ionov D.V. Diagnostika i lechebnaia taktika pri inorodnykh telakh zheludochno- kishechnogo trakta u detei: avtoreferat dissertatsii kandidata meditsinskikh nauk [Diagnosis and therapeutic tactics in case of foreign bodies of the ventricular tract in children: autoreferate of the thesis of the Candidate of Medical Sciences]. Moscow, 2015, 18 p. 
4. Salakhov E.S., Salakhov E.S. Fine-tine invagination as a rare early postoperative complication in a child after removal of foreign intestinal bodies (magnets) [Tonko-tonkokishechnaia invaginatsiia kak redkoe oslozhnenie $\mathrm{v}$ rannem posleoperatsionnom periode $\mathrm{u}$ rebenka posle udaleniia inorodnykh tel kishechnika (magnity)]. Russian Journal of Pediatric Surgery, Anesthesia and Intensive Care - Rossiiskii vestnik detskoi khirurgii, anesteziologii i reanimatologii, 2015, no. 5 (appl.), p. 139.

5. Strizhenok D.S., Batonov G.B., Rukevich S.G. Case of treatment of complicated foreign bodies of the gastrointestinal tract in a child [Sluchai lecheniia oslozhnennykh inorodnykh tel zheludochnokishechnogo trakta u rebenka]. Russian Journal of Pediatric Surgery, Anesthesia and Intensive Care - Rossiiskii vestnik detskoi khirurgii, anesteziologii i reanimatologii, 2015, no. 5 (suppl.), p. 145. 